\title{
Wpływ czynników religijnych na terapię uzależnień
}

Życie osób uzależnionych, które próbują wyjść z nałogu, a może precyzyjniej byłoby napisać - żyć godnie ze swoim nałogiem, jest ciągłą walką o swoją trzeźwość, wytrwałość i o samego siebie. Wszyscy, którzy mają takie doświadczenia, zgodnie przyznają, że w pewnym momencie musieli dobrowolnie zgodzić się przed samym sobą, a najczęściej także przed innymi ludźmi, że wobec substancji czy obiektów, od których są uzależnieni, stali się bezsilni. Skoro sami nie są w stanie sobie pomóc w pełni, to należy odwołać się do przestrzeni zewnętrznej. I tutaj natrafiamy na innych ludzi, ale także na płaszczyznę wiary, bo dla przeważającej ilości przypadków Bóg lub Absolut czy inna siła wyższa okazuje się odniesieniem koniecznym. Wie o tym każdy uzależniony, który próbuje walczyć ze swoim nałogiem i niwelować

1 Duszpasterz osób niepełnosprawnych i chorych. Od kilku lat współpracuje z krakowską fundacją ACAPE organizując wakacyjne wyjazdy rehabilitacyjno-rekolekcyjne dla niepełnosprawnych, doktorant w Katedrze Psychologii Pastoralnej UPJPII w Krakowie. W swoich zainteresowaniach naukowych skupia się na psychologii cierpienia, oddziaływaniu religii na osoby uzależnione, różnicach w duszpasterstwie mężczyzn i kobiet. Autor opublikowanych artykułów: Kościół „żeńskokatolicki”, czyli o tym, dlaczego mężczyźni nie chodzą do kościoła; Sakrament pokuty i pojednania a psychoterapia - próba ukazania wzajemnych relacji obu procesów oraz kilku artykułów internetowych z zakresu psychologii religii. 
go. Mówią o tym zresztą także dwa pierwsze kroki postępowania we wspólnotach samopomocowych dla osób uzależnionych ${ }^{2}$.

Anonimowe wspólnoty osób uzależnionych bardzo często działają we współpracy z Kościołem; możemy to zaobserwować szczególnie w Polsce i innych krajach katolickich. Ale nawet wtedy, gdy tego typu grupy nie mają związku z konkretną organizacją o charakterze wyznaniowym, to konieczne jest, by ich członkowie przynajmniej założyli, że istnieje Bóg lub inny byt transcendentny ${ }^{3}$.

W niniejszym artykule nie zostanie podjęte rozważanie na temat przydatności wiary podczas walki z nałogiem, bo jest ona oczywista, ale nastąpi refleksja nad tym, co konkretnie daje religia osobom uzależnionym. Jakie jej czynniki i aspekty wpływają pozytywnie na ten proces. To zagadnienie zostanie przedłożone nie tylko z perspektywy ściśle religijnej, ale także od strony wiary samej w sobie, właściwej dla każdego człowieka, niezależnie od wyznawanej religii. Artykuł jest opatrzony teoretycznym wstępem na podstawie szerokiej literatury psychologicznej, religijnej i terapeutycznej. Jednak zasadniczą jego część stanowi analiza wyników badań przeprowadzonych we wspólnotach Anonimowych Alkoholików (dalej AA), Anonimowych Narkomanów (NA) i Anonimowych Seksoholików (SA). Badania dotyczyły wiary uczestników oraz przydatności religii w ich zmaganiu z nałogiem. W dalszej części, w której poruszony zostanie temat tych wszystkich grup naraz, będą nazywane w skrócie grupami A.

\section{Związek terapii uzależnień z Kościołem katolickim w Polsce}

Zaznaczono już we wstępie, że w niektórych krajach (może szczególnie dobrze widać to w Polsce) terapia uzależnień ma duży związek

2 Por. B. Hamilton, 12 kroków ze sponsorem, tłum. J. Zuzanna, Poznań 1998.

3 Por. W. G. Wilson [Bill W.], Anonimowi Alkoholicy [Wielka księga], Warszawa 1989, s. $37-40$. 
z Kościołem katolickim. Dostrzegamy to zwłaszcza wśród wspólnot samopomocowych, czyli tzw. grup A. O szczegółach obecności tych grup w życiu społecznym i kościelnym będzie powiedziane dalej. Na początku jednak trzeba zastanowić się, skąd bierze się związek Kościoła $\mathrm{z}$ tego typu działaniami.

Kościół katolicki już od samych początków swojego istnienia prowadził działalność, którą moglibyśmy nazwać społeczno-charytatywną. Polegała ona na pomocy najuboższym i najbiedniejszym, a także na wskazywaniu życiowych zasad, które pozwalały na uniknięcie problemów, również związanych z uzależnieniami. I tak już w Pierwszym Liście do Koryntian św. Pawła Apostoła odnajdujemy wezwanie do unikania wszelkiej rozpusty ${ }^{4}$. W tym samym dziele Apostoł Narodów zakazuje wiernym być jakimkolwiek zgorszeniem dla innych ludzi ${ }^{5}$ i krytykuje pijaństwo ${ }^{6}$, a w Liście do Efezjan mówi bezpośrednio o konieczności bycia trzeźwym ${ }^{7}$. Kościół usilnie zaleca również post, w tym także od używek i substancji wyskokowych, jako środek do poprawy kondycji duchowej, psychicznej i fizycznej, a nieumiarkowanie w jedzeniu i piciu jest potępiane jako jeden z siedmiu grzechów głównych. Idea pomocy osobom potrzebującym rozwijała się w Kościele przez lata i dotyczyła również ludzi mających problem z niekontrolowanym korzystaniem z substancji uzależniających. Na ziemiach polskich przełomowym momentem w tej dziedzinie było powołanie Towarzystwa Trzeźwości przez ks. Jana Nepomucena Alojzego Ficka w połowie XIX wieku na Śląsku. Stowarzyszało ono ludzi dobrowolnie deklarujących abstynencję w czasach, kiedy fala alkoholizmu zalewała polskie społeczeństwo ${ }^{8}$.

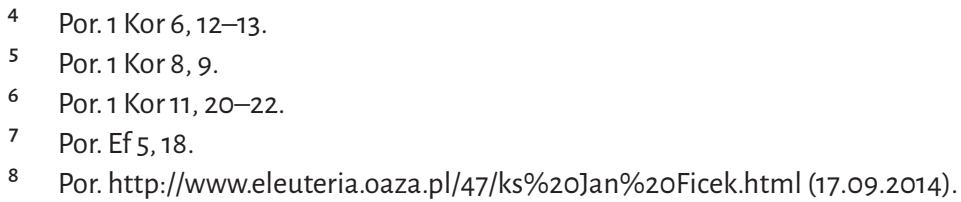


Do dzisiaj Kościół katolicki w Polsce jest ważnym środowiskiem, w którym rozwija się idea walki z nałogami9. Wiele ośrodków niosących pomoc osobom uzależnionym (najczęściej członkom grup A) $\mathrm{i}$ ich rodzinom pracuje właśnie $\mathrm{z}$ ramienia Kościoła. Trzeba tu podkreślić, że szczególnie mocno widać to $\mathrm{w}$ dziedzinie walki $\mathrm{z}$ alkoholizmem. Wystarczy spojrzeć na wykaz miejsc, gdzie odbywają się spotkania poszczególnych grup $\mathrm{AA}^{10}$, a dostrzeżemy ich dużą współpracę z Kościołem. Powoływane są ośrodki walki z uzależnieniami działające przy konkretnych wspólnotach czy zakonach. Duży udział w walce z nietrzeźwością ma Caritas Polska, która dotuje ich budo$\mathrm{we}^{11}$. Pomoc uzależnionym jest niesiona nie tylko w formie terapii obejmującej część somatyczną człowieka, ale również od strony duchowej. Trzeba podkreślić, że istnieje Zespół Konferencji Episkopatu Polski ds. Apostolstwa Trzeźwości, który koordynuje pracą duszpasterzy diecezjalnych ${ }^{12}$. W wielu parafiach funkcjonują bractwa trzeźwości będące bezpośrednimi spadkobiercami organizacji założonej w XIX wieku przez ks. Jana Ficka. Dużym uznaniem cieszą się nie tylko inicjatywy stałe, ale również okresowe, takie jak: pielgrzymka anonimowych alkoholików na Jasną Górę, w której uczestniczy co roku kilkanaście tysięcy osób, propagowanie sierpnia jako miesiąca trzeźwości czy organizacja rekolekcji i dni skupienia dla uzależnionych od alkoholu ${ }^{13}$.

9 Por. ].Zimniak, Rola Kościoła i wartości religijnych w profilaktyce uzależnień, [w:] Profilaktyka uzależnień droga do wolności człowieka, red. C. Cekiera, I. Niewiadomska, Lublin 2001, s. 67-72.

Por. http://www.aa.org.pl/mityngi/indexo05.htm (17.09.2014).

11 Por. https://ekai.pl/wierzenica-k-poznania-lecie-katolickiego-osrodka-terapiiuzaleznien/ (21.03.2017); http://www.bialystok.caritas.pl/p/index.php?optio$\mathrm{n}=$ com_content\&view=article\&id=107\&Itemid=67 (17.09.2014).

Por. http://www.duszpasterstwotrzezwosci.pl/index.php?option=com_content\&view=category\&layout=blog\&id=6\&Itemid=17 (17.09.2014). osób uzależnionych i współuzależnionych $w$ województwie małopolskim. Informa- 
Anonimowi alkoholicy to najczęściej ludzie wierzący. Takimi byli od początku lub odzyskali swoją wiarę na skutek przeżywanego kryzysu. Więcej na ten temat będzie powiedziane w ostatniej części artykułu, prezentującej analizę przeprowadzonego badania. Inaczej jest w przypadku wspólnot NA czy SA. Ta ostatnia jest stosunkowo młoda w Polsce, działa mniej niż 10 lat, stąd nie jest jeszcze tak mocno ustrukturyzowana i związana $\mathrm{z}$ jakąkolwiek grupą wyznaniową, choć jej członkowie najczęściej deklarują związek z Kościołem katolickim i dojrzale przeżywają swoją wiarę.

Z kolei organizacja grup NA jest zazwyczaj nieco inna. Ich członkowie są dużo bardziej zindywidualizowani, rzadziej wskazują na wiarę w takiego Boga, jakiego obraz niesie ze sobą doktryna katolicka. Ich wiara, choć jest obecna i ważna w walce $\mathrm{z}$ nałogiem, jawi się bardziej jako hybryda luźnych poglądów i zasad skumulowanych w niespójną całość. Również sama organizacja tych wspólnot często jest oderwana od życia Kościoła. Ciekawą inicjatywą w tym względzie są wspólnoty Cenacolo, które oferują uzależnionym ludziom wspólne życie i dach nad głową. Poprzez dostosowanie się do wymaganej wewnątrz każdego domu dyscypliny ich mieszkańcy mogą zmierzyć się ze swoim uzależnieniem. Pomysłodawczynią była katolicka siostra zakonna włoskiego pochodzenia Elwira Petrozzi ${ }^{14}$.

Więzi Kościoła z różnymi grupami, wspólnotami, organizacjami czy ośrodkami działającymi na rzecz uzależnionych wynikają przede wszystkim z wiary ich uczestników, a także z troski o dobro czło-

tor, Kraków 2008, s. 158-161; Komisja Episkopatu Polski ds. Trzeźwości, Duszpasterskie pro memoria dla duchowieństwa $w$ Polsce w sprawie systematycznej realizacji wytycznych Episkopatu Polski dla kościelnej działalności trzeźwościowej, [w:] Przesłanie nadziei. Przewodnik dla duszpasterstwa trzeźwości, red. M. Dziewiecki, Warszawa 1993, s. 195-205.

14 Por. http://win.comunitacenacolo.it/viewpagina.asp?keypagina=726\&idlingua $=9(21.03 .2017)$. 
wieka we wszystkich jego wymiarach (nie tylko duchowym, ale też fizycznym i psychicznym), co bezpośrednio łączy się z nauką Jezusa Chrystusa.

\section{Terapeutyczna funkcja religii}

Funkcji religii jest wiele i istotnie wpływa ona na jej wyznawców, o ile podchodzą do niej w sposób dojrzały i poważny. Jedną z podstawowych funkcji religii jest funkcja terapeutyczna. Zasadniczo nikt nie ma wątpliwości co do jej zasadności w przypadku sfery duchowej człowieka, jako że sama z natury bezpośrednio się z nią łączy. Prowadzone są szerokie dyskusje na temat wpływu wiary na ludzką psychikę, a w szczególności tego, jaki ten wpływ jest: pozytywny czy negatywny. Najbardziej dyskusyjną kwestię stanowi tutaj jednak związek religii z terapią i możliwością leczenia człowieka pod względem fizycznym - somatycznym. Nauka chce dystansować się od wydarzeń nadzwyczajnych, czyli tzw. cudów, które często są wątpliwe. Inną, otwartą kwestią jest to, czy istnieje realny wpływ religii na zdrowie człowieka bez cudownych doświadczeń, tylko tak po prostu, jako pewne stałe doświadczenie. Niezależnie od poglądów i opinii raczej powszechnie uznaje się terapeutyczną funkcję religii, a wiele badań wykazało jej istnienie.

Do zagadnienia terapeutycznych właściwości możemy podejść w dwojaki sposób. Po pierwsze wertykalnie, rozpatrując relację i odniesienie konkretnej jednostki do Boga. Po drugie - horyzontalnie, spoglądając na relację danej osoby z tym wszystkim, co jest związane z otoczeniem religii: wspólnotą wiernych, wytwarzaną przy okazji kulturą i wszystkimi dodatkowymi instytucjami, akcjami czy wydarzeniami toczącymi się „przy okazji” religii ${ }^{15}$. 
W pierwszym przypadku - podejściu wertykalnym - brana jest pod uwagę relacja i stosunek do Boga, umiejętność odnalezienia sensu swojego życia w oparciu o Jego osobę, odnajdywania odpowiedzi na nurtujące i podstawowe pytania oraz praktycznego zastosowania zasad, jakie daje religia. Osoby, które potrafią spojrzeć na tragiczne wydarzenia w swoim życiu (np. śmierć bliskich, choroba czy nałóg) jako na Boży plan wobec nich, mniej boleśnie je znoszą. Są pogodzone z zaistniałą sytuacją i łatwiej podejmują walkę o poprawę stanu swojego bytu, szczególnie wtedy, kiedy motywuje ich do tego wyznawana wiara. Możemy tu mówić o pozytywnym odniesieniu do Boga; kluczowe w tym wypadku jest zaufanie Mu. Istnieje też odniesienie negatywne, związane z obwinianiem Go za doznawane problemy. W odniesieniu wertykalnym istotne jest także wzmocnienie duchowe, które rozwija się pod wpływem częstego stosowania strategii kontaktu z Bogiem, co z kolei daje pozytywne efekty przezwyciężania sytuacji granicznych (a do takich z pewnością należy nałóg ${ }^{16}$ ). Co ciekawe, wzmocnienie duchowe nie jest zależne od poziomu depresji, ale wymagana tu jest ludzka aktywność. Z drugiej strony bierne oczekiwanie na Bożą interwencję rzadziej prowadzi do przekonania o tym, że przeżywane doświadczenia są wynikiem Bożej woli i ogranicza osoby do podejmowania inicjatyw o słabej skuteczności w przezwyciężaniu problemów. Podstawowym czynnikiem terapeutycznym nierozerwalnie związanym $\mathrm{z}$ religią jest kształtowanie nadziei. Właściwie wszystkie religie, posiadające osobowy obraz Boga, dają perspektywę na przyszłość w życiu pozaziemskim, wiecznym. Dlatego nadzieja, kształtowana i wzmacniana przez religię, nadaje sens życiu człowieka ${ }^{17}$, co staje się często najważniejszym motywatorem w przeżywaniu trudnych doświadczen ${ }^{18}$.

16 Por. H. Piszkalski, Problem „sytuacji granicznych” w ujęciu Karla Jaspersa, „Analecta Cracoviensia"X (1978), s. 107-109.

17 Por. J. P. Marciniak, Próba zastosowania Viktora Emila Frankla koncepcji rozwoju noetycznego w programie terapii uzależnień, Zakroczym 2009, s. 90-94.

18 Por. M. Wnuk, J. T. Marcinkowski, Psychologiczne..., dz. cyt., s. 240-241. 
Jeśli chodzi o czynniki horyzontalne mające wpływ na terapeutyczne funkcjonowanie religii, to należy tu wymienić przede wszystkim oddziaływanie wspólnoty. Osoby zaangażowane w wyznawanie jednej religii już z założenia są razem i dzielą identyczne lub przynajmniej zbliżone poglądy, tym samym otrzymując od siebie ogromne wsparcie. Może ono zachodzić w przestrzeni obecności i bycia razem, co motywuje i wzmacnia do pokonywania trudnych sytuacji. Może też przejawiać się w konkretnej, jednostkowej pomocy (np. modlitwa, wsparcie materialne, skierowanie do specjalistów).

Oprócz samej wspólnoty ludzi w religii mamy też do czynienia z całym zestawem przepisów i wskazań mówiących o tym, czym wierni powinni kierować się w życiu. Bardzo często dotyczą one nie tylko dobra duchowego, ale także fizycznego - albo, żeby doprecyzować: przez dobro fizyczne prowadzą do duchowego. Przykładami mogą być post, zakaz spożywania nieodpowiednich potraw i napojów czy zalecenie bycia przyzwoitym. Choć są to kwestie oczywiste, jeśli chodzi o pozytywny wpływ na ludzi, to jednak dopiero autorytet religii może nakłonić do ich praktykowania. W tej przestrzeni kluczowe pojęcia, jakie się pojawiają i które są wiodące w procesie wzmacniania jednostki, to wsparcie ${ }^{19}$ i motywacja ${ }^{20}$.

Sebastian Murken wymienia następujące czynniki jako naczelne w przypadku terapeutycznego oddziaływania religii: zachowania (wpływ religii na ludzkie zachowanie), ws pa rcie (odniesienie i sieć powiązań ze wspólnotą), koherencja (religijna interpretacja sytuacji), coping (większa aktywność w poszukiwaniu odpowiedzi przez osoby religijne), poczucie własnej wartości (religia podnosi poziom poczucia godności) ${ }^{21}$.

19 Por. M. Wnuk, J. T. Marcinkowski, Psychologiczne..., dz. cyt., s. 241.

20 Por. I. Niewiadomska, M. Kalinowski, D. Sikorski, Kulty publiczności, Lublin 2005, S. 21-23.

21 Por. S. Murken, Gottesbeziehung und psychische Gesundheit. Die Entwicklung eines Modells und seine empirische Überprüfung, Münster 1998, s. 75. 
W procesie leczenia i zdrowienia bardzo ważna wydaje się także wiara sama w sobie, tzn. taka, która jest oderwana od konkretnej religii (co nie oznacza, że nie może z nią współwystępować, a wydaje się nawet, że powinna). Wiara taka stoi u podstaw każdego ludzkiego organizmu, który z natury jest istotą wierzącą, a wybór przedmiotu wierzenia jest już efektem poznania i doświadczenia, jakich nabywa ludzkość w procesie rozwoju cywilizacyjnego ${ }^{22}$. Omawiane zjawisko wzmaga w człowieku nadzieję (kluczową do tego, by móc w ogóle pokonywać negatywne sytuacje graniczne), a polega na głębokim przekonaniu w powodzenie obranych środków i metod działania. Joseph Murphy w swoim dziele Potęga podświadomości deprecjonuje nawet wiarę religijną na rzecz nadziei i wiary wypływających z naszej osoby w procesie przeżywania cierpienia ${ }^{23}$. Oczywistym jest, że taka postawa pełna wiary i nadziei jest konieczna, ale w oderwaniu od konkretnego wierzenia i relacji z Bogiem tworzy tak naprawdę zwrot ku sobie samej - wiarę w swoją doskonałość lub zwrot ku jednostkom i obiektom, które pomogły danej osobie pokonać trudną sytuację. Wtedy następuje ubóstwienie ludzi lub przedmiotów.

Przedstawione zostało pewne spojrzenie na religię, pod kątem jej terapeutycznych właściwości. Nie wolno jednak zapominać także o możliwościach bezpośredniej interwencji Boga w życie osób dotkniętych problemami, tak by nie sprowadzić wiary ludzi tylko do procesu biologicznego, zachodzącego jedynie w ludzkim mózgu. Liczne uzdrowienia i zdarzenia nadzwyczajne sugerują, że działanie Boga jest możliwe; tym samym wpływają one wzmacniająco na innych wierzących, dotkniętych podobnymi problemami. wa 2013, s. 10-12, 50-51. 


\section{Rola religii w procesie wychodzenia z nałogu}

Jak już powiedziano, religia spełnia wiele funkcji, a jedną z podstawowych jest oddziaływanie terapeutyczne. Można zatem postawić sobie pytanie, czy istnieje, a jeśli tak, to jaki jest wpływ religii na szeroko pojęte życie w nałogu (odzyskiwanie godności, procesy walki i wychodzenia z niego, życia bez substancji lub obiektu uzależniającego). Warto zagłębić się i spróbować wydobyć elementy obecne w każdej religii mające faktyczny wpływ na poprawę kondycji osób uzależnionych. W zasadniczej części tego artykułu przyglądniemy się badaniu, które pomoże nam dostrzec te najistotniejsze, w odczuciu samych uzależnionych, czynniki poprawiające ich stan życia.

Jednym z podstawowych aspektów religii, jaki niewątpliwie mocno wpływa na skuteczne podjęcie walki z nałogiem, jest obraz Boga. Od tego zależy cały kształt wyznawanej wiary, wraz z jej zasadami i wskazaniami. Żyjąc w środowisku europejskim, przez lata przyzwyczailiśmy się do chrześcijaństwa, które niesie ze sobą Boga - dobrego i miłosiernego Ojca, gotowego na przyjęcie każdego człowieka, niezależnie od kryzysu czy upadku, w jakim się znajduje. Oczywiście trzeba przyznać, że ten obraz często bywał i bywa nadal zniekształcany. Szczególnie przed Soborem Watykańskim II Boga postrzegano bardziej jako bezwzględnego Sędziego, niż miłosiernego Ojca, a w wychowaniu stawiano na żelazną dyscyplinę. Taka aberracja mogła prowadzić często do patrzenia z pogardą na ludzi, którzy popadli w nałóg i mają problem „na własne życzenie”. Sytuacja nieco zmieniła się, kiedy od 1956 roku alkoholizm oraz uzależnienia od substancji narkotykowych zostały wciągnięte na listę chorób Światowej Organizacji Zdrowia (WHO) ${ }^{24}$. Nieco później nadszedł czas Soboru, a co za tym idzie - nowego spojrzenia na przestrzeń wiary katolickiej, sposób przedstawienia Boga oraz zadania Kościoła. Wrócono do korzeni religii, która jednoznacznie 
mówi o miłosiernym Bogu, wychodzącym do każdego człowieka, nawet marnotrawnego syna ${ }^{25}$. Wydaje się więc, że chrześcijaństwo, a szczególnie obrządek katolicki, mają najbardziej dogodny dla osób przeżywających kryzysy obraz Boga. Już z samego założenia jest On nastawiony pozytywnie do człowieka, nie uzależniając tego od kondycji duchowej, psychicznej czy fizycznej. Takie podejście prowadzi do wzmocnienia poczucia wartości i godności wiernych ${ }^{26}$, powinno również ograniczać strach i lęk przed karą, choć wyeliminowanie ich w pełni jest raczej niemożliwe ${ }^{27}$. We wspólnotach chrześcijańskich niekatolickich sytuacja wygląda różnie i ze względu na olbrzymią ich ilość trudno ujednolicić w prosty sposób obraz Boga, jaki posiadają reprezentujący je wyznawcy. Zauważa się jednak u nich tendencję do mocno zindywidualizowanego wyobrażenia o Bogu, a w skrajnych przypadkach można nawet mówić o swoistej hybrydzie osobistych poglądów i indyferentyzmie religijnym. Taka sytuacja powoduje nieraz brak stałej linii spostrzeżeń, jakie mogłyby wypływać z wierzeń danej wspólnoty dla dobra osób znajdujących się w kryzysie nałogowym.

Jeśli chodzi o wpływ obrazu Boga w religiach niechrześcijańskich na przydatność terapeutyczną religii, to jest on zdecydowanie mniejszy niż w przypadku wyznawców Chrystusa. Jeśli weźmiemy pod uwagę religie monoteistyczne (judaizm i islam), to dojdziemy do wniosku, że Bóg jest tam o wiele bardziej oddalony od człowieka niż w chrześcijaństwie i spełnia raczej rolę sędziego oraz prawodawcy. W związku z tym jest bardziej obojętny na losy człowieka, także tego pokrzywdzonego $\mathrm{w}$ jakimkolwiek wymiarze ${ }^{28}$. Jego funkcja chowa 1995, s. 95-96.

27

28

Por. Łk 15, 11-32.

Por. W. Wermter, Nadzieja dla alkoholików. O roli wiary w leczeniu z nałogu, Często-

Por. A. Baran, Duchowa terapia osób uzależnionych, Warszawa 2006, s. 15-45.

Por. K. Kościelniak, Chrześcijaństwo w spotkaniu z religiami świata, Kraków 2006, S. 173-174, 202-204; T. Dzidek, Ł. Kamykowski, A. Kubiś, Teologia fundamentalna, t. 2, Religie świata a chrześcijaństwo, Kraków 1998, s. 88-92, 99-102. 
wypełnia się przede wszystkim w ocenie moralnej człowieka, choć nie wyklucza też interwencji, która może nieść ze sobą pomoc. Pozostałe wielkie religie Wschodu (taoizm, konfucjanizm, szintoizm czy buddyzm) widzą Boga jako bezosobowy Absolut lub system filozoficzny ${ }^{29}$, co również nie sprzyja bliskiej relacji z ludźmi, a wręcz ją uniemożliwia. Wierni którejś z tych religii mogą być zdani na siebie oraz na życiowe zasady wynikające $\mathrm{z}$ ich wierzeń, ale raczej nie powinni liczyć na osobową relację, która mogłaby uzdrowić. Wyjątkowy okazuje się politeistyczny hinduizm, który dodatkowo nie dostrzega wartości w cierpieniu ani nie szanuje człowieka przechodzącego trudne etapy w swoim życiu. Ideałem jest tutaj dostatnie, obfite życie, a wszelkie kryzysy stoją z nim w sprzeczności i są efektem nieodpowiedniego życia w poprzednim wcieleniu ${ }^{30}$.

Innym kluczowym czynnikiem mającym terapeutyczny wymiar jest wspólnota ${ }^{31}$, o której zostało już dużo powiedziane na początku. Oczywiście można wskazać religie bardziej wspólnotowe i takie, w których wierni są bardziej zindywidualizowani. Spośród wielkich religii świata to właśnie te wschodnie stawiają w większym stopniu na niezależność swoich wyznawców. Często brak w nich jednolitego systemu doktrynalnego i centralnego ośrodka koordynującego (np. w szintoizmie, taoizmie czy konfucjanizmie) ${ }^{32}$. Różnorodność wewnętrznych wierzeń wśród poszczególnych odłamów jest tak duża, że trudno mówić o jednej dużej religii, a można raczej

Por. K. Kościelniak, Chrześcijaństwo..., dz. cyt., s. 72-73, 91-93, 114-116, 132-133, 154155; T. Dzidek, Ł. Kamykowski, A. Kubiś, Teologia..., dz. cyt., s. 28-33, 47-51, 57$62,69-72,78-80$.

Por. K. Kościelniak, Chrześcijaństwo..., dz. cyt., s. 73-74.

Por. L. Carre, Nie byłam już sama, [w:] Fundacja Biuro Służby Krajowej Anonimowych Alkoholików w Polsce, Uwierzyliśmy...: przygoda duchowa AA w doświadczeniu poszczególnych uczestników Wspólnoty, Warszawa 2013, s. 24-25; A. Baran, Duchowa..., dz. cyt., s. 143-169.

Por. K. Kościelniak, Chrześcijaństwo..., dz. cyt., s. 136, 150. 
o konglomeracie mniejszych wyznań, połączonych jakąś wspólną cechą. Dodatkowo biorąc pod uwagę fakt, że często są to właściwie systemy filozoficzne, bywają one dyskusyjne, nawet na forum wewnętrznym danej religii. Taka sytuacja na pewno nie ułatwia tworzenia ścisłych wspólnot; dogodniejsze do tego są religie monoteistyczne jako lepiej zorganizowane od strony strukturalnej. Wspólnoty są wyraźnie widoczne w judaizmie i islamie, a jeszcze bardziej w chrześcijaństwie. Zwłaszcza w tym ostatnim kładzie się szczególny nacisk na życie wspólnotowe, do którego zachęcał sam Chrystus oraz jego następcy. Swoistym przykładem takiej wspólnoty jest Kościół tworzący Mistyczne Ciało Chrystusa i zjednoczony ze swoim Mistrzem; także niektóre kościoły protestanckie bardzo mocno opierają się na zasadzie komunii ich członków. W tej kwestii widać również, że chrześcijaństwo posiada najdogodniejsze warunki do zacieśniania relacji międzyludzkich oraz Bosko-ludzkich, co ma duży wpływ na właściwości terapeutyczne religii.

Kolejna ważna przestrzeń religii stanowiąca o jej terapeutyczności to cały zbiór zasad etycznych i moralnych. Wypływające z wiary reguły mogą być istotne, a nawet kluczowe w podejściu wiernego do kwestii substancji i obiektów uzależniających. Widać tu bardzo duże podobieństwo głównych religii świata, które zasadniczo potępiają nadużywanie substancji odurzających takich jak alkohol czy narkotyki. W przypadku np. islamu zakaz spożycia alkoholu jest całkowity, choć $\mathrm{w}$ praktyce różnie respektowany. Zalecane też są zasadniczo czystość i asceza, czyli umiar w korzystaniu z różnorodnych używek. To wszystko prowadzi do profilaktyki nałogów, czyli działań, a może bardziej precyzyjnie byłoby napisać - postaw prewencyjnych, które okazują się najskuteczniejszymi w walce z uzależnieniami w odniesieniu do ogółu społeczeństwa ${ }^{33}$. Podobieństwo tych

33 Por. Z. B. Gaś, Uzależnienia. Skuteczność programów profilaktyki, Warszawa 1994, s. $8-14$. 
wskazań we wszystkich wielkich religiach świata bierze się stąd, że $\mathrm{w}$ zasadzie każda $\mathrm{z}$ nich wiąże się $\mathrm{w}$ jakimś stopniu $\mathrm{z}$ prawem naturalnym, gdzie jednym z filarów jest ochrona życia i dbanie o jego wysoką jakość. Niezależnie od tego, czy jest to chrześcijaństwo lub islam z wyraźnie osobowym Bogiem, czy wschodnia filozofia, jak taoizm, to zawsze w centrum postawione jest dobro osoby. Oczywiście trzeba podkreślić ogromną siłę chrześcijańskiego personalizmu w wieloaspektowym oddziaływaniu na człowieka i zaznaczyć to, o czym już powiedziano - duży związek środowiska terapeutycznego osób uzależnionych z Kościołem. Ten fakt po raz kolejny stawia katolików w uprzywilejowanej pozycji w kontekście omawianego zagadnienia.

Poza wymienionymi elementami religijności, kluczowymi dla terapii uzależnień, nie można zapomnieć o możliwości działania nadprzyrodzonego. To kwestia bardzo indywidualna, subiektywna i praktycznie nieporuszana na łamach naukowych polemik. Jednocześnie jej wykluczenie redukuje religię wyłącznie do wymiaru intelektualnego ${ }^{34}$. Trzeba jednak podkreślić nieporównywalną z innymi religiami bliskość Kościoła z Bogiem poprzez Jego bezpośrednią obecność w sakramentach, szczególnie Eucharystii. To daje katolikom bardzo pozytywne perspektywy w otwarciu się na Boga i jego działanie $^{35}$.

Występują też inne ważne czynniki składowe religii, które można poddawać analizie i rozpatrywać ich przydatność w terapii uzależnień. Dotychczas wzięto pod uwagę te uznane przez autora artykułu za najważniejsze. W dalszej części zostaną omówione wyniki badań, jakie udało się uzyskać w ramach anonimowej ankiety, przeprowadzanej w lipcu i sierpniu 2014 roku wśród 53 członków AA, NA i SA.

Por. T. Dzidek, Ł. Kamykowski, A. Napiórkowski, Teologia fundamentalna, t. 5, Poznanie teologiczne, Kraków 2006, s. 158-159. dz. cyt., s. 110-117. 


\section{Analiza wyników badań}

\subsection{Religijność ankietowanych}

Jak często uczestniczysz obecnie we mszy świętej?

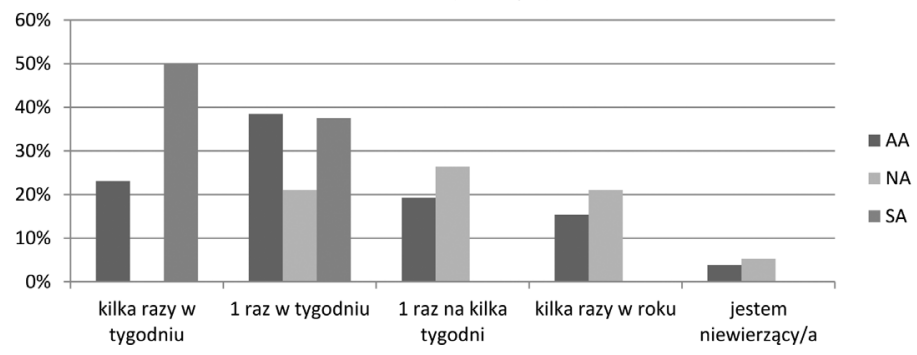

Wykr. 4.1.1. Uczestnictwo we mszy świętej-obecnie

Jak często uczestniczyłeś/aś we mszy świętej przed wstąpieniem do grupy wsparcia?

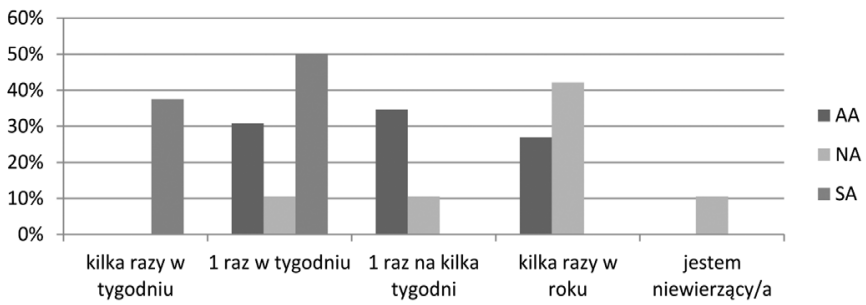

Wykr. 4.1.2. Uczestnictwo we mszy świętej - przed przystąpieniem do grupy samopomocowej

Pierwsze pytanie dotyczyło uczestnictwa we mszy świętej w chwili obecnej oraz przed wstąpieniem do anonimowych grup wsparcia i miało za zadanie sprawdzenie pod tym względem religijności an- 
kietowanych. Okazuje się, że spośród trzech grup (AA, NA i SA) najbardziej zaangażowani religijnie są anonimowi seksoholicy. Większość z nich (88 proc.) uczestniczy we mszy świętej przynajmniej raz w tygodniu lub więcej. Obecnie ta grupa częściej chodzi na mszę świętą kilka razy w tygodniu niż przed wstąpieniem do SA.

Kolejna mocno zaangażowana grupa to AA. Spośród jej członków dwie trzecie deklaruje uczestnictwo w Eucharystii kilka lub przynajmniej jeden raz w tygodniu. W przypadku alkoholików dostrzegamy duży wzrost pobożności, gdyż przed wstąpieniem do grupy również dwie trzecie z nich stwierdzało, że na mszę świętą chodzi kilka razy w roku lub jeden raz na kilka tygodni.

Najmniejszy odsetek dominicantes jest wśród narkomanów, spośród których tylko co piąty deklaruje regularne, cotygodniowe uczestnictwo we mszy świętej; trzeba natomiast podkreślić, że stanowi to dwa razy więcej niż przed wstąpieniem do NA. Pozostali nie chodzą do kościoła w ogóle lub robią to sporadycznie. Nikt nie bierze udziału w Eucharystii częściej niż raz w tygodniu.

Kolejne zadane pytanie jest powiązane z pierwszym i dotyczy podejmowanych praktyk religijnych innych niż uczestnictwo we mszy świętej - obecnie oraz w okresie przed wstąpieniem do grupy wsparcia.

Jakie praktyki religijne podejmujesz obecnie oprócz uczestnictwa we mszy świętej?

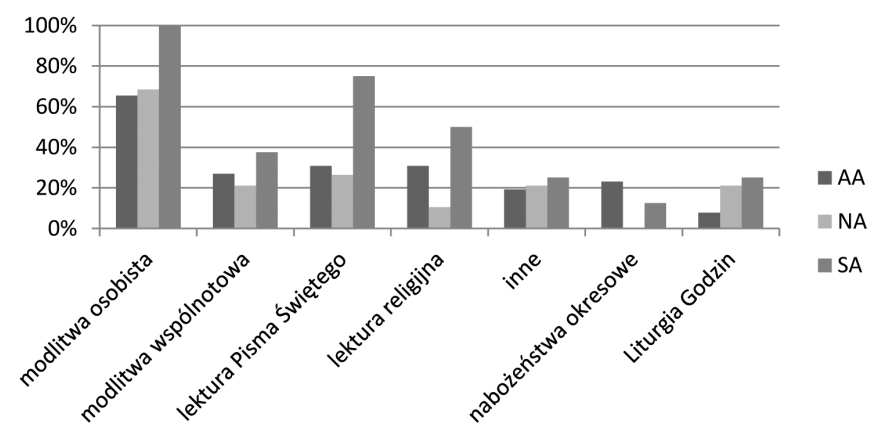

Wykr. 4.1.3. Dodatkowe praktyki religijne-obecnie 
Czy przed wstąpieniem do grupy wsparcia podejmowałeś/aś dodatkowe praktyki religijne?

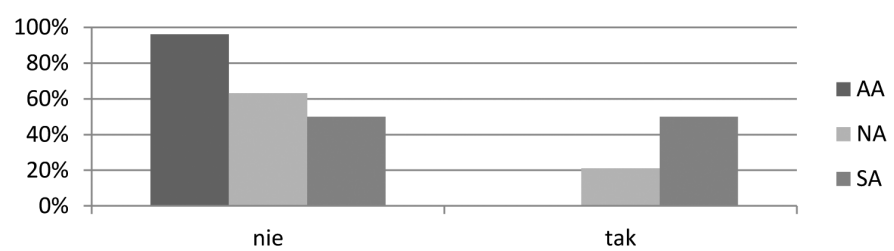

Wykr. 4.1.4. Dodatkowe praktyki religijne-przed wstąpieniem do grup wsparcia

Zauważamy, że najczęstszą podejmowaną praktyką religijną jest modlitwa osobista (powyżej 65 proc. w każdej grupie), lektura Pisma Świętego i modlitwa wspólnotowa (21-75 proc. w zależności od grupy). Podobnie jak w przypadku uczestnictwa we mszy świętej widzimy największą aktywność wśród SA i AA oraz dużo mniejszą wśród NA.

W zestawieniu z sytuacją sprzed wstąpienia do grupy wsparcia zauważamy wyraźny wzrost, jeśli chodzi o podejmowanie praktyk religijnych. Ci, którzy przyznawali się do takiego działania, wymieniali jako najczęstsze modlitwę osobistą i lekturę Pisma Świętego. Narkomani są jedynymi, którzy nie podejmowali wcześniej tego rodzaju praktyk.

Po analizie odpowiedzi na pierwsze pytania dochodzimy do wniosku, że uczestnicy SA i AA są osobami wierzącymi i praktykującymi, które w większości regularnie uczestniczą we mszy świętej i podejmują dodatkowe inicjatywy religijne. Anonimowi narkomani natomiast nie odczuwają już tak często takiej potrzeby. Widzimy też, że wstąpienie do grupy wsparcia powoduje wzrost dynamizmu wiary. Nałóg i uświadomienie sobie go paradoksalnie często zatem są przyczyną zwrotu do Boga.. 


\subsection{Osobista relacja do Boga}

Co czułeś/aś względem Boga, kiedy uświadomiłeś/aś sobie swój problem (uzaleznienie)?

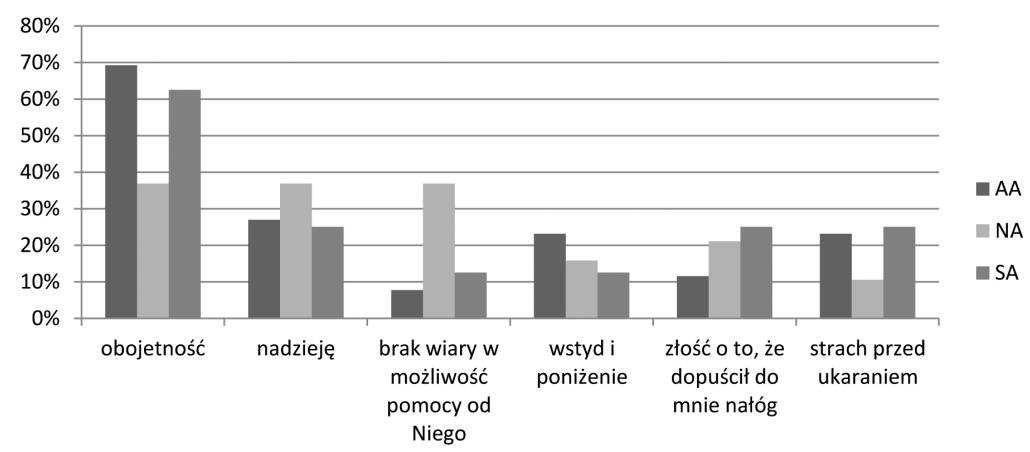

Wykr. 4.2.1. Odczucia względem Boga towarzyszące uświadomieniu sobie swojego problemu (nałogu)

Z powyższego wykresu wynika, że najczęstszym odczuciem, jakie pojawiało się wraz z uświadomieniem sobie swojego problemu przez ankietowanych, była obojętność wobec Boga. Respondenci nierzadko wybierali w tym pytaniu kilka odpowiedzi, stąd również wysoko uplasowały się nadzieja i - w przypadku grupy NA - brak wiary w Jego pomoc. Odczucia negatywne, jak złość, wstyd czy strach przed karą, nie były najpopularniejszym wyborem, choć wskazał je nawet co czwarty ankietowany.

$\mathrm{W}$ innym miejscu zapytano ankietowanych o ich bezpośredni stosunek do Boga w czasie obecnym. Również tutaj wybierano więcej niż jedną odpowiedź, ale tą najczęstszą okazała się: troskliwy ojciec. Wskazało ją, w zależności od grupy, 37-88 proc. odpowiadających. Oprócz tego Bóg pomaga naszym respondentom $\mathrm{w}$ walce $\mathrm{z}$ nałogiem (21-63 proc.) i często jest w niej ich partnerem (11-38 proc.), 
a niekiedy nawet walczy za samych uzależnionych (ponad jedna trzecia NA i SA, nikt spośród AA). Warto też dostrzec, że nikt z SA nie określił Go jako obojętnego i tylko przedstawiciele AA powiedzieli, że jest sędzią.

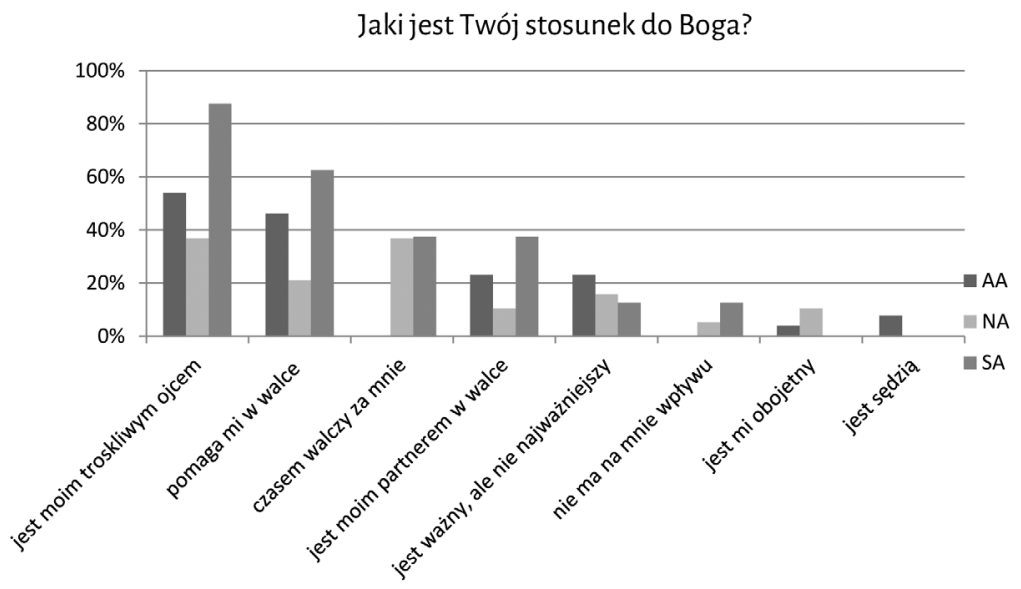

Wykr. 4.2.2. Stosunek ankietowanych do Boga

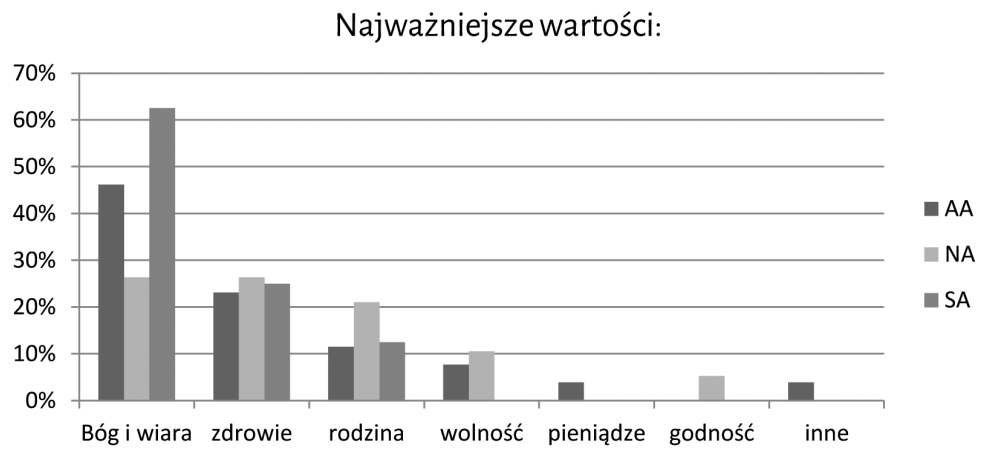

Wykr. 4.2.3. Najważniejsze wartości 
Pytanie o najważniejsze wartości w życiu jednoznacznie pokazuje, że dla wszystkich badanych grup Bóg i wiara są na pierwszym miejscu (46 proc. AA, 26 proc. NA i 63 proc. SA), choć w przypadku członków NA równie wartościowe jest zdrowie. Takie podejście po raz kolejny świadczy o dojrzałej wierze i dobrze przeżywanej religijności przez członków AA i SA, wśród których to Bóg odgrywa najistotniejszą rolę.

Warto zauważyć, jak małą popularnością cieszyły się godność i wolność jako najważniejsze wartości. Być może dlatego, że są one efektem bliskości Boga (najpopularniejsza odpowiedź) i ofiarowywane jako Jego dar każdemu wierzącemu, dlatego nie musiały pojawić się jako oddzielne wskazania. W sytuacji osób uzależnionych są to wartości bardzo ważne i mocno pożądane.

Wyniki odpowiedzi z tych pytań korespondują z innymi, które również dotyczyły przeszłości respondentów. Duża część z nich była bierna w kwestiach religijnych i nie praktykowała swojej wiary (por. 4.1. Religijność ankietowanych), stąd może wynikać większa obojętność wobec Boga i oddalenie od Niego w przeszłości oraz o wiele bardziej optymistyczny model tych relacji obecnie. Dla badanych Bóg z czasem przybrał obraz pozytywny. Jest dobrym, miłosiernym Ojcem, który przede wszystkim pomaga, a nie karze czy upomina. Właśnie taki obraz Boga wypływa z głęboko i dobrze przeżywanej wiary chrześcijańskiej. Widać zatem po raz kolejny, że świadomość nałogu i chęć podjęcia z nim walki wymusiła pogłębienie swojej wiary, zmieniła podejście religijne osób uzależnionych i zbliżyła je do Boga. Taką dynamikę rozwoju wiary podali także sami uzależnieni w pytaniu, gdzie mieli wybrać spośród określeń „kryzys”, „zaangażowanie”, „obojętnośćc te, które odpowiadały poszczególnym okresom życia. Ich spostrzeżenia i opinie w tej kwestii obrazuje poniższy model: 


\begin{tabular}{|c|c|c|}
\hline OBOJĘTNOŚć & KRYZYS & ZAANGAŻowANIE \\
\hline $\begin{array}{c}\text { Przed wejściem } \\
\text { w nałóg }\end{array}$ & $\begin{array}{c}\text { Podczas nałogu - przed } \\
\text { wstąpieniem do wspólnoty }\end{array}$ & $\begin{array}{c}\text { Po wstąpieniu do } \\
\text { wspólnoty }\end{array}$ \\
\hline
\end{tabular}

Ryc. 1. Dynamika wiary w zetknięciu z nałogiem

4.3. Konkretne elementy religii wpływające pozytywnie na życie z uzależnieniem

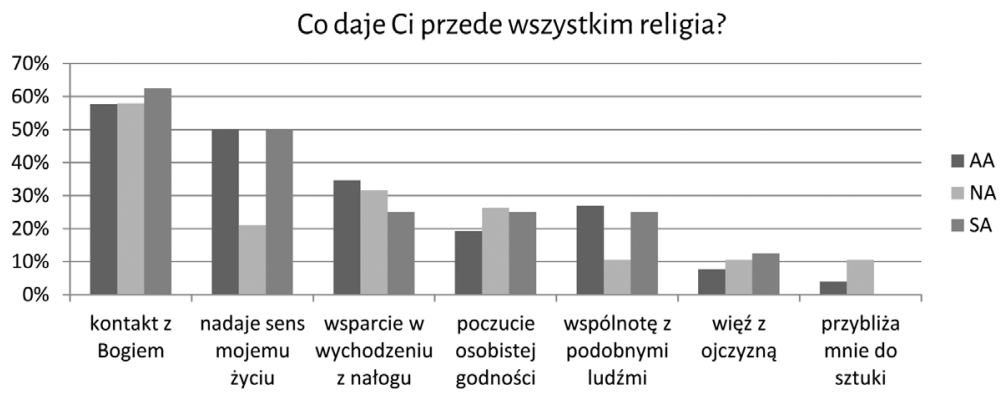

Wykr. 4.3.1. Najważniejsze czynniki religijne w życiu uzależnionych

Powyższy wykres obrazuje, co daje religia osobom uzależnionym, jakie konkretne czynniki pozytywnie wpływają na nie oraz ich życie z tym problemem. Widzimy, że najważniejszy dla ankietowanych jest kontakt z Bogiem, jaki wypływa z praktykowania religii. Wszystkie trzy grupy były pod tym względem wyjątkowo zgodne i tę odpowiedź wskazało 58-63 proc. respondentów. Dla członków AA i SA prawie równie ważny jest sens, jaki płynie z religii (tę możliwość wybrało 
50 proc. ankietowanych $\mathrm{z}$ obu wspomnianych grup), jednocześnie zauważamy mały odsetek osób z NA, które zdecydowały się na wskazanie tej odpowiedzi (21 proc.).

Zaskakujący może być rzadki wybór wspólnoty (szczególnie w przypadku NA - tylko 11 proc.; dla pozostałych 25-27 proc.) i bezpośredniego wsparcia w wychodzeniu z nałogu (25-35 proc.) jako kluczowych elementów wynikających z religii. Można zatem wnioskować, że religijność ankietowanych jest dojrzała i terapia uzależnień nie stanowi jej podstawowej funkcji. Ten leczniczy wpływ wydaje się wtórny - jako następstwo głębokiego kontaktu z Bogiem, ale nie wolno nam zapominać, że ów kontakt w większości przypadków został nawiązany w sytuacji własnej bezsilności wobec uzależnienia (por. ryc. 1. Dynamika wiary w zetknięciu $\mathrm{z}$ nałogiem).

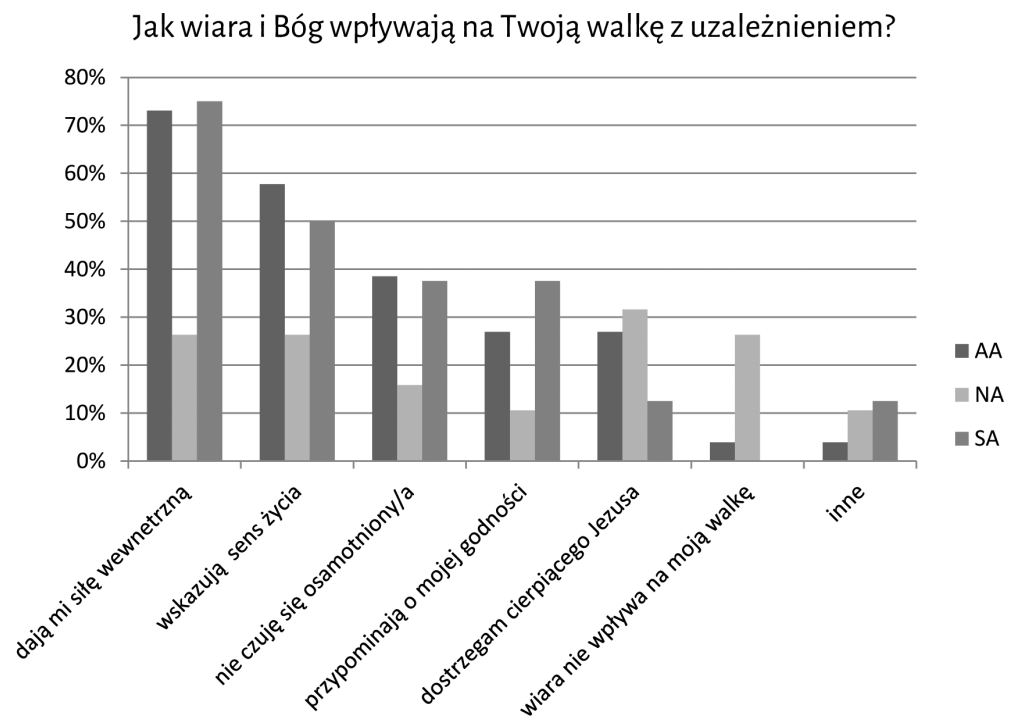

Wykr. 4.3.2. Wpływ Boga i religii na walkę z uzależnieniem 
Ostatni wykres obrazuje, jakie zdaniem ankietowanych są najważniejsze aspekty religijne, które wpływają pozytywnie na życie $\mathrm{z}$ nałogiem i możliwość podjęcia $\mathrm{z}$ nim walki.

Najważniejszy czynnik, jaki wypływa z religii i wiary w Boga, to siła wewnętrzna (wskazywali na nią uczestnicy wszystkich grup w różnym stopniu - od 26 do 75 proc.). Jest ona potrzebna do podjęcia jakiejkolwiek walki, szczególnie z tak trudnym doświadczeniem, jak uzależnienie; wiąże się ona $\mathrm{z}$ przekonaniem, nadzieją i wiarą w zwycięstwo oraz motywacją do działania.

Na drugim miejscu pojawiło się wskazanie przez Boga i religię prawdziwego sensu życia. Tę odpowiedź wybierało, w zależności od grupy, od 26 do 58 proc. badanych. Poczucie sensu w sytuacji człowieka uzależnionego jest również bardzo ważne, gdyż motywuje do działania i pokazuje perspektywę dalszą, wykraczającą poza substancję czy obiekt uzależniający. Jednocześnie daje nadzieję na szczęście rozumiane metafizycznie.

Kolejny często (od 16 do 38 proc. w zależności od grupy) wskazywany czynnik to wspólnota. Religia staje się lekarstwem na samotność i opuszczenie, które nierzadko wiążą się z nałogiem. Zostało już dużo powiedziane o leczniczym wpływie, jaki wspólnota wywiera na swoich członków w sytuacjach granicznych (por. 2. Terapeutyczna funkcja religii). Oprócz wspólnoty rozumianej w sposób zwyczajny, jako łączność z innymi ludźmi, dzięki głęboko przeżywanej religii powstaje także bardzo intymna wspólnota $\mathrm{z}$ Bogiem, a fakt ten również może wywierać wpływ terapeutyczny.

Warto też zwrócić uwagę, że co czwarty spośród anonimowych narkomanów nie dostrzega związku religii i Boga z jego walką z nałogiem. Po raz kolejny ta wspólnota okazuje się bardziej obojętna religijnie od pozostałych.

W ostatnim pytaniu poproszono ankietowanych o samodzielną opinię na temat ich oceny wpływu religii i wiary w Boga na życie w stanie uzależnienia i na wychodzenie z nałogu. Wypowiedzi były różne, od kilkuwyrazowych po obszerne opisy zachodzących prze- 
mian. W przeważającej części respondenci mówili o Bogu i wyznawanej religii jako o wielkim dobru, dzięki któremu udaje im się żyć i wychodzić stopniowo z uzależnienia. Wskazywano na ogrom łaski, jaka płynie od Boga w sytuacjach granicznych. Bóg także motywuje, wspiera, niekiedy walczy wraz z osobą uzależnioną, wskazuje cel, daje wiarę (również w siebie i swoje możliwości). Religia oprócz darów nadprzyrodzonych wprowadza we wspólnotę podobnych ludzi, mających swoje problemy. Kilka osób stwierdziło także, że niezwykle cenny jest przykład Jezusa, który sam cierpiał i dlatego jest bliski ludziom. Wypowiedzi niektórych ankietowanych sugerowały, że wiara stanowi ostatnią wartościową przestrzeń, jaka pozostała w ich życiu.

Niewielu spośród wypowiadających się stwierdziło, że wciąż poszukuje Boga i pragnie Go odnaleźć. Pojawiło się też kilka poglądów sceptycznych, o zabarwieniu agnostyckim, według których nie ma podstaw, by łączyć wychodzenie z nałogu z jakąkolwiek Bożą interwencją.

Zazwyczaj tymi, którzy mieli duże wątpliwości co do realnego wpływu Boga i religii na ich uzależnienie, byli anonimowi narkomani. Może wynikać to z krótkiego stażu badanych członków tej grupy, przez co nie przeszli oni jeszcze takiego rozwoju swojej wiary jak inni, będący dłużej w pozostałych wspólnotach (duża część respondentów wśród NA w momencie badań uczestniczyła w terapii dopiero od kilku miesięcy). Inna przyczyna takiego stanu rzeczy tkwi w charakterze grup NA i stawianiu przede wszystkim na wartości ludzkie ${ }^{36}$. Z kolei alkoholicy i seksoholicy podchodzili bardzo pozytywnie do takiej zależności. 


\section{Podsumowanie}

Po przeanalizowaniu wszystkich udzielonych przez uzależnione osoby odpowiedzi na zadane pytania dochodzimy do kilku ciekawych wniosków dotyczących relacji religii i życia w stanie nałogu.

Po pierwsze zauważamy wzrost jakości życia religijnego respondentów pod wpływem uświadomienia sobie swojego problemu związanego z uzależnieniem. Ten związek jest dwubiegunowy, gdyż $\mathrm{z}$ jednej strony głębokie życie religijne pozwala na lepsze radzenie sobie $\mathrm{z}$ nałogiem, a $\mathrm{z}$ drugiej - to zaangażowanie jest wynikiem świadomości swojego problemu. Ankietowani po uprzytomnieniu sobie tego, w jakiej znajdują się sytuacji, postanowili poszukać pomocy m.in. u Boga i w religii. To z kolei przyniosło pożądane efekty. Widzimy zdecydowany rozwój religijności u osób uczestniczących od dłuższego czasu w spotkaniach grup A. Jednocześnie widzimy mniejsze zaangażowanie w sprawy wiary u tych, którzy są w takich zbiorowościach od niedawna (mniej niż dwa lata).

Po drugie dostrzegamy też rozwój obrazu Boga wraz z samoświadomością nałogu. Podstawowym odczuciem, jakie pojawiało się wraz z uświadomieniem sobie swoich problemów, była obojętność. Obecnie Bóg jawi się jako dobry Ojciec, który pomaga i wspiera osoby uzależnione.

Całość przebiegu dynamiki wiary moglibyśmy zobrazować ogólnym schematem, w którym obojętność jest obecna w życiu jeszcze przed pojawieniem się nałogu, kryzys następuje w okresie przed wstąpieniem do jednej z grup A, a po dłuższym pobycie w takiej wspólnocie rodzi się zaangażowanie (por. ryc. 1. Dynamika wiary w zetknięciu z nałogiem). Oczywiście schemat jest ogólny, zbudowany na podstawie statystycznej większości podawanych odpowiedzi, a w pojedynczych przypadkach istnieją odchylenia od tej normy.

Po trzecie najważniejszymi czynnikami, jakie religia daje badanym, są osobisty kontakt z Bogiem, prawdziwy sens życia oraz wspar- 
cie w nałogu. Taki zestaw sugeruje, że respondenci w tym momencie przeżywają dojrzale swoją wiarę, a elementy lecznicze są czerpane jakby pośrednio, tzn. religia nie staje się jedynie źródłem terapii, ale odgrywa ważniejszą rolę. Sam jej wpływ na uzależnienie to efekt dodatkowy.

Po czwarte według ankietowanych tym, co Bóg daje im bezpośrednio do podejmowania walki z nałogiem, są siła wewnętrzna, odkrycie i poczucie sensu życia oraz przezwyciężenie samotności. Te odpowiedzi potwierdzają, że kluczowy w terapii uzależnień z religijnej perspektywy jest obraz Boga. Bóg osobowy, miłosierny i jednocześnie bliski człowiekowi motywuje do walki i wskazuje dalszą, pozaziemską perspektywę życia, o którą warto się starać i dla której warto przezwyciężyć wszelkie trudności. Drugi najistotniejszy element kształtujący życie z uzależnieniem to wspólnota, której zalety zostały wymienione we wstępie. Dotyczy to dwóch rodzajów wspólnoty: osobistej więzi z Bogiem oraz relacji do innych wyznawców tej samej religii i członków grupy.

Trzeba też podkreślić, że w wypowiedziach badanych Bóg i wiara pojawiają się generalnie jako czynniki niezbędne do godnego życia w nałogu i możliwości wychodzenia $\mathrm{z}$ niego. Respondenci podkreślają uzdrawiającą moc płynącą od Boga, głównie poprzez nadanie sensu, motywacji i wsparcia. Wielu z nich wskazuje także na przeżycie swoistych cudów nawrócenia religijnego i cudów związanych z leczeniem ich organizmu z nałogów. Oczywiście wypowiedzi nie są jednolite i pojawiają się też sceptyczne względem relacji Boga i religii do stanu życia uzależnionych, ale większość badanych dostrzega taki związek, a nawet nie wyobraża sobie życia bez niego.

Jak widać $\mathrm{z}$ analizy wyników badań przeprowadzonych wśród anonimowych alkoholików, anonimowych seksoholików i anonimowych narkomanów, potwierdzone zostało to, co powiedziano o leczniczym wpływie religii na sytuacje graniczne. Można zauważyć pozytywne oddziaływanie religii nie tylko na sferę duchową, ale również 
somatyczną człowieka. Niestety w trakcie badań nie udało dotrzeć się do innych wspólnot tego typu (np. anonimowych hazardzistów czy uzależnionych od urządzeń elektronicznych), jednak biorąc pod uwagę niedługą obecność tych grup w przestrzeni społecznej, można założyć, że są one zbliżone do tych, które brały udział w ankiecie, bo na nich się wzorowały. 